\title{
Abnormal steroid excretion in gestational trophoblastic disease complicated by ovarian theca-lutein cysts
}

\author{
BR BEVAN, M SAVVAS, JM JENKINS, KARINE BAKER, \\ GW PENNINGTON, NF TAYLOR* \\ From the Jessop Hospital for Women, Sheffield, *Northwick Park Hospital, Middlesex
}

SUMMARY Serum and urine steroids were examined in two subjects with trophoblastic disease accompanied by large ovarian theca-lutein cysts and compared with those from 10 patients with trophoblastic disease but without palpable cysts. In the patients without cysts normal values were obtained for serum oestradiol, progesterone, $17 \alpha$-hydroxyprogesterone and androstenedione, and for urinary total oestrogens, pregnanediol, pregnanetriol, and 17-oxosteroids. Nineteen urinary steroid metabolites, quantified by capillary gas-liquid chromatography, were either within reference limits or marginally raised. In several cases relatively minor increases in serum testosterone and cortisol and urinary free cortisol were observed. In contrast, the subjects with cysts showed pronounced excesses of androgen metabolites, 17 $\alpha$-hydroxypregnanolone, pregnanediol, and pregnanetriol, and both exhibited a similar pattern of unusual additional metabolites.

The profiles superficially resembled those seen in 21-hydroxylase deficiency adrenogenital syndrome, but there were important discrepancies reflecting known differences in ovarian and adrenal steroid metabolism.

Chemotherapy led to decline of human chorionic gonadotrophin concentrations, regression of the cysts, and return to normal of the steroid profile. Excess steroids in the patients with cysts may have originated in the ovary rather than in the trophoblastic tissue.

Steroid excretion in subjects with trophoblastic disease has been little studied but has, in most cases, been reported as within normal limits. Urinary pregnanediol (Table 1) and oestrogens are seldom increased over non-pregnant concentrations, ${ }^{12}$ and trophoblastic tissue is limited in its capacity to synthesise steroids. ${ }^{3-5}$

During routine follow up of subjects with gestational trophoblastic disease two patients had raised concentrations of human chorionic gonadotrophin (hCG) and large theca-lutein cysts of the ovary. In contrast to the other subjects with trophoblastic disease in whom ovarian cysts were not a feature, plasma and urinary steroids in these two patients were increased. Indeed, some steroids were present in very high quantities.

To delineate further the nature and extent of the abnormality urinary steroid metabolites were examined by capillary gas-liquid chromatography and gas

Accepted for publication 9 January 1986 chromatography-mass spectrometry. Ten further subjects with gestational trophoblastic disease but without palpable ovarian cysts were also studied to determine whether the subjects with cysts would show a discrete disorder or one extreme of a continuum. This also permitted an assessment of whether these unusual metabolites originated in the trophoblastic tissue or the ovary.

\section{Case histories}

\section{CASE 1}

A 23 year old primigravida had an evacuation of a hydatidiform mole at about 12 weeks' gestation. One month later she was admitted for chemotherapy in view of raised urinary hCG concentrations (9830 IU/24 hours), persistent irregular vaginal blood loss, dyspnoea, chest pain, and colicky abdominal pain. Clinically, she had a bulky uterus with a large separate mass arising from the pelvis. Ultrasonography showed this to be an ovarian cyst $22 \mathrm{~cm}$ 
Table 1 Non-standard abbreviations and trivial names of steroid compounds

\section{Trivial names:}

Testosterone

Androsterone

$11 \beta$-Hydroxyandrosterone

Aetiocholanolone

$11 \beta$-Hydroxyaetiocholanolone

11-Oxo-aetiocholanolone

Androstenedione

Androstenetriol

Dehydroepiandrosterone (DHA)

$16 \alpha$-Hydroxy DHA

Pregnenolone

$17 \alpha$-Hydroxypregnenolone

$16 \alpha$-Hydroxypregnenolone

Progesterone

16 $\alpha$-Hydroxyprogesterone

Pregnanediol

Pregnanolone

$17 \alpha$-Hydroxyprogesterone

$17 \alpha$-Hydroxypregnanolone

Pregnanetriol

11-Deoxycortisol

Tetrahydro-11-deoxycortisol

Cortisol

Tetrahydrocortisol

allo-Tetrahydrocortisol

Tetrahydrocortisone

Tetrahydro-11-dehydrocorticosterone

Tetrahydrocorticosterone

allo-Tetrahydrocorticosterone

$\alpha$-Cortolone

$\beta$-Cortolone

$\alpha$-Cortol

$\beta$-Cortol

Oestrone

Oestradiol

\section{Systematic names:}

17 $\beta$-Hydroxy-4-androsten-3-one

$3 \alpha$-Hydroxy-5 $\alpha$-androstan-17-one

$3 \alpha, 11 \beta$-Dihydroxy-5 $\alpha$-androstan-17-one

$3 \alpha$-Hydroxy-5 $\beta$-androstan-17-one

$3 \alpha, 11 \beta$-Dihydroxy-5 $\beta$-androstan-17-one

$3 \alpha$-Hydroxy-5 $\beta$-androstane-11, 17-dione

4-Androstene-3, 17-dione

5 -Androstene-3 $\beta, 16 \alpha, 17 \beta$-triol

$3 \beta$-Hydroxy-5-androsten-17-one

$3 \beta, 16 \alpha$-Dihydroxy-5-androsten-17-one

$3 \beta$-Hydroxy-5-pregnen-20-one

$3 \beta, 17 \alpha$-Dihydroxy-5-pregnen-20-one

$3 \beta, 16 \alpha$-Dihydroxy-5-pregnen-20-one

4.Pregnene-3, 20-dione

16 $\alpha$-Hydroxy-4-pregnene-3, 20-dione

$5 \beta$-Pregnane-3 $\alpha, 20 \alpha$-diol

$3 \alpha$-Hydroxy-5 $\beta$-pregnan-20-one

$17 \alpha$-Hydroxy-4-pregnene-3, 20-dione

$3 \alpha, 17 \alpha$-Dihydroxy-5 $\beta$-pregnan-20-one

$5 \beta$-Pregnane-3 $\alpha, 17 \alpha, 20 \alpha$-triol

$17 \alpha, 21$-Dihydroxy-4-pregnene-3, 20-dione

$3 \alpha, 17 \alpha, 21$-Trihydroxy-5 $\beta$-pregnan-20-one

$11 \beta, 17 \alpha, 21$-Trihydroxy-4-pregnene-3, 20-dione

$3 \alpha, 11 \beta, 17 \alpha, 21$-Tetrahydroxy-5 $\beta$-pregnan-20-one

$3 \alpha, 11 \beta, 17 \alpha, 21$-Tetrahydroxy-5 $\alpha$-pregnan-20-one

$3 \alpha, 17 \alpha, 21-$ Trihydroxy-5 $\beta$-pregnane-11, 20-dione

$3 \alpha, 21$-Dihydroxy-5 $\beta$-pregnane-11, 20-dione

$3 \alpha, 11 \beta, 21$-Trihydroxy-5 $\beta$-pregnan-20-one

$3 \alpha, 11 \beta, 21-T$ rihydroxy-5 $\alpha$-pregnan-20-one

$3 \alpha, 17 \alpha, 20 \alpha, 21$-Tetrahydroxy-5 $\beta$-pregnan-11-one

$3 \alpha, 17 \alpha, 20 \beta, 21-T e t r a h y d r o x y-5 \beta$-pregnan-11-one

$5 \beta$-Pregnane-3 $\alpha, 11 \beta, 17 \alpha, 20 \alpha, 21$-pentol

$5 \beta$-Pregnane-3 $\alpha, 11 \beta, 17 \alpha, 20 \beta, 21$-pentol

3-Hydroxy-1, 3, 5(10)-Oestratriene-17-one

$1,3,5(10)$-Oestratrien-3, 17 $\beta$-diol in diameter. A chest radiograph showed multiple pulmonary metastases.

She received five courses of methotrexate with folinic acid rescue, two courses of second line treatment (actinomycin D, cyclophosphamide, and vincristine),

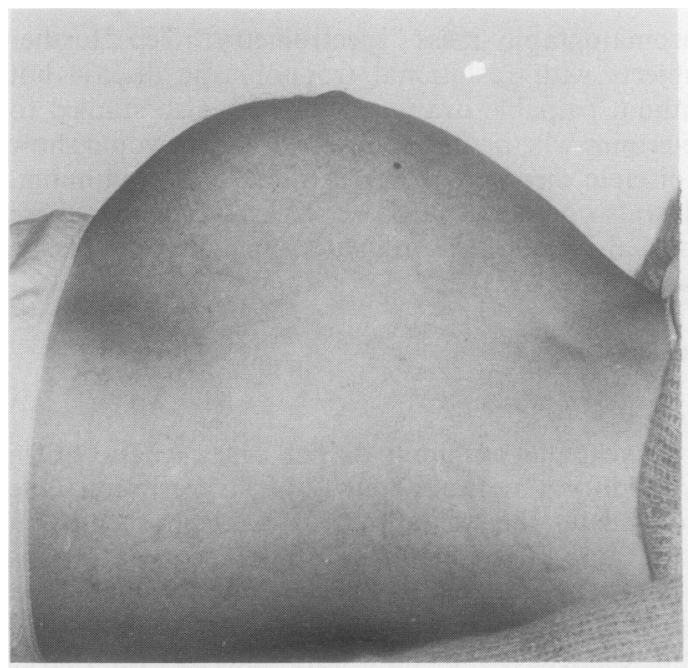

Fig. 1 Abdominal enlargement (case 1) due to ovarian tumour and six courses of VP16 (etoposide) in accordance with a modification of the regimen used by Bagshawe. ${ }^{6}$ Urine and serum hCG concentrations fell to within normal limits, and pelvic examination yielded normal results. Eighteen months later recurrent trophoblastic tumour was diagnosed by rising urinary hCG concentrations. Chest radiography and ultrasonography yielded normal results and the steroid urinary excretion profile was also normal. The recurrence responded to two courses of methotrexate and five courses of VP16.

\section{CASE 2}

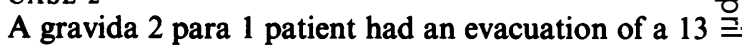
week gestation hydatidiform mole at the age of 25 . N Six weeks later she presented with a raised serum $\beta$ hCG concentration of $21030 \mathrm{IU} / \mathrm{l}$, urinary hCG of $\mathrm{N}$ $16480 \mathrm{IU} / 24$ hours, gross abdominal distension $\omega$ (Fig. 1), and amenorrhoea. Examination showed a cystic swelling arising from the pelvis, and ultrasonography showed this to be consistent with a large $\mathbb{\Phi}$ ovarian cyst (Fig. 2). Chest $x$-ray showed multiple pulmonary metastases. She received five courses of methotrexate and five courses of second line treatment after which a chest radiograph, ultra-

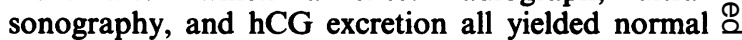
results. 


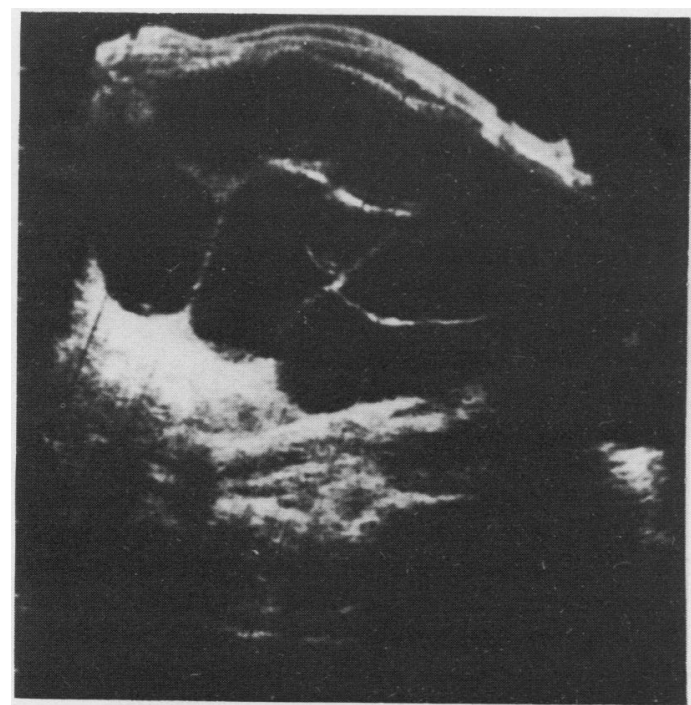

Fig. 2 Ultrasound scan of multicystic mass (case 1) arising from ovary

For comparison purposes 10 other patients undergoing follow up for trophoblastic disease were also screened before chemotherapy was started. At the time of screening hCG excretions varied between 45000 and $459000 \mathrm{IU} / 24$ hours, but theca-lutein cysts of the ovary, when present, were only barely palpable.

\section{Material and methods}

Samples of blood from an antecubital vein were taken without anticoagulant and the serum separated by centrifugation as soon as practicable. Twenty four hour urine samples were collected into containers with $10 \mathrm{ml}$ of $1 \%$ boric acid as preservative. Unless assayed within 24 hours, the separated serum and aliquots of urine were kept at $-20^{\circ} \mathrm{C}$ until analysed. All samples were obtained on admission of the patient to hospital for chemotherapy.

\section{URINARY STEROID PROFILE ANALYSIS}

Urinary steroids were extracted from $10 \mathrm{ml}$ portions of urine using Sep-Pak C18 cartridges. ${ }^{7}$ This method provides recoveries of standard steroids of $87-103 \% .^{7}$ Conjugates were hydrolysed using $100 \mu \mathrm{l}$ Helix pomatia digestive juice containing 10000 Roy units of sulphatase and 10000 Fishman units of $\beta$ glucuronidase (Reactifs IBF, Villeneuve-La-Garenne,

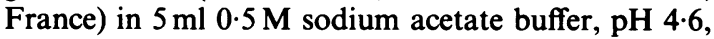
and incubated for 48 hours at $37^{\circ} \mathrm{C}$. Conditions were chosen to produce maximal yield of free steroids.

Glucuronides and 3-sulphates are efficiently hydrolysed, while 17-sulphates of $\mathrm{C}_{19}$ steroids and 21 -sulphates of $C_{21}$ steroids are relatively resistant to this procedure. Freed steroids were extracted on Sep-Pak cartridges as before. After addition of internal standards methyloxime-trimethylsilyl ether (MO-TMS) derivatives were made ${ }^{8}$ and analysed on a

Table 2 Urinary steroid profiles

\begin{tabular}{|c|c|c|c|c|c|}
\hline \multirow[t]{3}{*}{ Steroid ( $\mu \mathrm{mol} / 24$ hours) } & \multirow{3}{*}{$\begin{array}{l}\text { Methylene } \\
\text { unit Nos }\end{array}$} & \multirow{3}{*}{$\begin{array}{l}\text { Ten cases of choriocarcinoma } \\
\text { without large theca-lutein } \\
\text { cysts } \\
\text { Range }\end{array}$} & \multicolumn{2}{|c|}{ Case Nos } & \multirow{3}{*}{$\begin{array}{l}\text { Reference } \\
\text { range }\end{array}$} \\
\hline & & & \multirow[t]{2}{*}{1} & \multirow[t]{2}{*}{2} & \\
\hline & & & & & \\
\hline 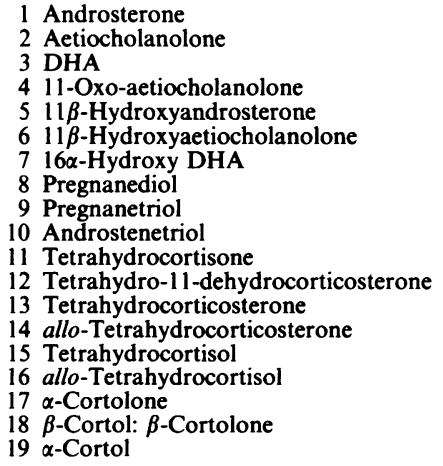 & $\begin{array}{l}25 \cdot 16 \\
25 \cdot 33 \\
25 \cdot 85 \\
26 \cdot 28 \\
27 \cdot 00 \\
27 \cdot 22 \\
27 \cdot 37 / 27 \cdot 41 \\
27 \cdot 64 \\
27 \cdot 98 \\
28 \cdot 41 \\
29 \cdot 68 \\
29 \cdot 77 \\
30 \cdot 00 \\
30 \cdot 10 \\
30 \cdot 23 \\
30 \cdot 39 \\
30 \cdot 52 \\
30 \cdot 81 \\
31 \cdot 20\end{array}$ & $\begin{aligned} 0 \cdot 3-10 \cdot 2(5 \cdot 8)^{1} \\
0 \cdot 4-6 \cdot 9 \\
<0 \cdot 1-0 \cdot 4 \\
0 \cdot 3-1 \cdot 3 \\
0 \cdot 6-3 \cdot 1 \\
<0 \cdot 1-1 \cdot 7(0 \cdot 7)^{2} \\
<0 \cdot 1-1 \cdot 3 \\
0 \cdot 9-4 \cdot 4 \\
0 \cdot 2-2 \cdot 9 \\
0 \cdot 1-1 \cdot 2 \\
2 \cdot 4-8 \cdot 7(6 \cdot 7)^{1} \\
0 \cdot 1-0 \cdot 5 \\
<0 \cdot 1-0 \cdot 3 \\
<0 \cdot 1-0 \cdot 5 \\
1 \cdot 1-5 \cdot 6(2 \cdot 6)^{2} \\
<0 \cdot 1-2 \cdot 5(2 \cdot 1)^{1} \\
0 \cdot 7-4 \cdot 8(2 \cdot 1)^{2} \\
0 \cdot 4-3 \cdot 2 \\
0 \cdot 1-1 \cdot 2(0 \cdot 7)^{1}\end{aligned}$ & $\begin{array}{r}27.2 \\
14.6 \\
1.7 \\
4.7 \\
95.1^{*} \\
2.4^{\circ} \\
-7 \\
18.7 \\
104.0 \\
3.4 \\
3.9 \\
0.1 \\
0.1 \\
0.1 \\
1.6 \\
2.0 \\
1.4 \\
0.6 \\
0.2\end{array}$ & $\begin{array}{r}37 \cdot 2 \\
58 \cdot 4 \\
-5.6 \\
36 \cdot 6 \\
140 \cdot 0^{*} \\
5 \cdot 3^{\circ} \\
11 \cdot 1 \\
39 \cdot 1 \\
143 \cdot 0 \\
12 \cdot 3 \\
12 \cdot 1 \\
0.7 \\
-1 \cdot 1 \\
12 \cdot 5 \\
4.8 \\
5 \cdot 0 \\
4.9 \\
2.2\end{array}$ & $\begin{array}{l}2.1-6.5 \\
2.7-6.9 \\
0.2-1.0 \\
0.1-0.8 \\
1.2-3.8 \\
0.3-0.9 \\
0.6-1.3 \\
0.4-4.8 \\
1.0-4.2 \\
0.3-1.9 \\
3.9-7.7 \\
0.1-0.4 \\
0.2-0.7 \\
0.4-0.8 \\
1.3-2.7 \\
0.9-2.3 \\
0.7-1.9 \\
0.9-3.7 \\
0.4-0.7\end{array}$ \\
\hline
\end{tabular}

Values in parentheses $=$ highest values when 1 or 2 results disregarded.

* On this profile $17 \alpha$-hydroxypregnanolone $(20)$ and $11 \beta$-hydroxyandrosterone (5) could not be separated (gas-chromatography-mass spectrometry showed that principal contributor to peak was $17 \alpha$-hydroxypregnanolone).

${ }^{\circ}$ Peak overlaid with $3 \alpha$-hydroxy-5 $\beta$-pregnane-20-one.

- Steroid not found.

Conversion to traditional units: $\mathrm{g}=\mathrm{mol} \times$ molecular weight. 
Table 3 Additional steroids present in urinary profiles from both patients*

\begin{tabular}{|c|c|c|c|}
\hline \multirow[t]{2}{*}{ Steroid ( $\mu \mathrm{mol} / 24$ hours) } & \multirow[t]{2}{*}{ Methylene unit Nos } & \multicolumn{2}{|c|}{ Case Nos } \\
\hline & & $I$ & 2 \\
\hline 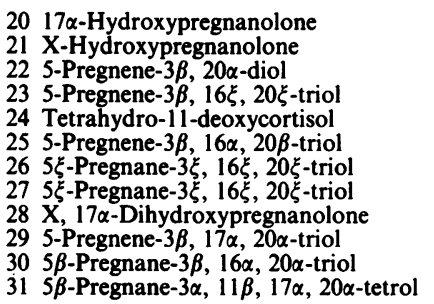 & $\begin{array}{l}27 \cdot 00 \\
28 \cdot 15 \\
28 \cdot 24 \\
28 \cdot 52 \\
28 \cdot 67 \\
28 \cdot 77 \\
28 \cdot 81 \\
28 \cdot 90 \\
29 \cdot 31 \\
29 \cdot 47 \\
29 \cdot 72 \\
29 \cdot 92\end{array}$ & $\begin{array}{c}95 \cdot 1 \dagger \\
9 \cdot 0 \\
1.0 \\
4 \cdot 6 \\
3 \cdot 8 \\
3 \cdot 2 \\
2 \cdot 2 \\
3 \cdot 3 \\
2 \cdot 7 \\
1 \cdot 6 \\
4 \cdot 4\end{array}$ & $\begin{array}{r}140 \dagger \\
21 \cdot 1 \\
7 \cdot 4 \\
12 \cdot 2 \\
11 \cdot 8 \\
8 \cdot 6 \\
5 \cdot 2 \\
2 \cdot 4 \\
2 \cdot 0 \\
8 \cdot 5 \\
3 \cdot 0 \\
12 \cdot 0\end{array}$ \\
\hline
\end{tabular}

* Usually present $<0.7 \mu \mathrm{mol} / 24$ hours.

†This peak also contains a very minor contribution from $11 \beta$-hydroxyandrosterone.

- Steroid not found.

Table 4 Urine and plasma steroids in trophoblastic disease

\begin{tabular}{|c|c|c|c|c|}
\hline \multirow[t]{2}{*}{ Steroid } & \multirow{2}{*}{$\begin{array}{l}\text { Values in } 10 \text { cases } \\
\text { without pronounced } \\
\text { theca-lutein cysts }\end{array}$} & \multicolumn{2}{|c|}{ Case Nos } & \multirow{2}{*}{$\begin{array}{l}\text { Reference } \\
\text { range }\end{array}$} \\
\hline & & 1 & 2 & \\
\hline \multicolumn{5}{|c|}{ Urine sample (nmol/24 hours (a)) ( $\mu \mathrm{mol} / 24$ hours (b)) } \\
\hline $\begin{array}{ll}\text { Total oestrogen } & \text { a } \\
\text { Pregnanediol } & \text { b } \\
\text { Pregnanetriol } & \text { b } \\
\text { Free cortisol } & \text { a } \\
\text { Oxosteroids } & \text { b }\end{array}$ & $\begin{array}{c}34-328 \\
0 \cdot 8-25 \\
<0 \cdot 2-4 \cdot 4 \\
71-620(2) \\
12-45\end{array}$ & $\begin{array}{r}4560 \\
139 \\
208 \\
343 \\
84\end{array}$ & $\begin{array}{c}\overline{137} \\
41^{*} \\
-\end{array}$ & $\begin{array}{l}28-338 \\
0 \cdot 4-27 \\
0 \cdot 3-5 \cdot 3 \\
97-331 \\
18-53\end{array}$ \\
\hline $\begin{array}{l}\text { Serum sample (nmol/l (oes } \\
\text { Oestradiol } \\
\text { Progesterone } \\
\text { 17-Hydroxyprogesterone } \\
\text { Cortisol } \\
\text { Testosterone } \\
\text { Androstenedione }\end{array}$ & $\begin{array}{l}<100-1773 \\
6-26 \\
2 \cdot 1-17 \\
219-1267(4) \\
0 \cdot 5-3 \cdot 5(4) \\
1 \cdot 0-9 \cdot 9\end{array}$ & $\begin{array}{c}5969 \\
210 \\
21^{*} \\
949 \\
25 \\
-\end{array}$ & $\begin{array}{r}>3690 \\
40 \\
192 \\
821 \\
36 \\
>32\end{array}$ & $\begin{array}{c}74-1840 \\
1-64 \\
1-18 \\
166-660 \\
0 \cdot 5-2 \cdot 5 \\
4 \cdot 0-10 \cdot 2\end{array}$ \\
\hline
\end{tabular}

No of cases with values above the upper limit of the normal range are shown in parentheses.

Reference range dependent on stage of menstrual cycle.

* Sample obtained after cytotoxic treatment had been started.

- Not done.

Packard 429 gas chromatograph (Packard Instrument, Caversham, England) containing a $25 \mathrm{~m}$ silica capillary column, $0.32 \mathrm{~mm}$ internal diameter, coated with CP Sil 5, thickness 0.13 $\mu$ m (Chrompack UK). Conditions were: $100-180^{\circ}$ at $20^{\circ} \mathrm{C} /$ minute followed by $180-275^{\circ}$ at $2.5^{\circ} \mathrm{C} /$ minute, injector and detector at $250^{\circ} \mathrm{C}$, carrier gas helium, $2 \mathrm{ml} /$ minute. $^{8}$

Mass spectra were obtained of all components using a Varian 112 instrument (Varian Associates, Walton-on-Thames, Surrey). ${ }^{8}$ A compound was considered to be fully identified when retention time and mass spectrum matched those of standard compounds (obtained from the Medical Research Council Steroid Reference Collection, Queen Mary College, London). Partial identifications were obtained when mass spectra were similar to those of standard compounds but did not have matching retention times. Tables 2 and 3 show methylene unit values as an aid to characterising the partially identified components.
OTHER STEROID ASSAY METHODS

Urinary total oestrogen concentrations were assayed by a fluorimetric semiautomated procedure based on the method of Lever et al ${ }^{9}$ with prior separation of oestrogens on columns of Sephadex G-10 (Pharmacia Limited, Milton Keynes, Bedfordshire, United Kingdom) according to GH Beastall (personal communication). Pregnanediol and pregnanetriol concentrations were quantified by gas chromatographic techniques based on the methods of Podmore ${ }^{10}$ and Curtius, ${ }^{11}$ respectively, and 17 -oxosteroids by the technique of Gray et al. ${ }^{12}$

Serum oestradiol, progesterone, cortisol (and urine free cortisol), and testosterone were assayed by kits obtained, respectively, from Steranti (Steranti Research Limited, St Albans, Herts, United Kingdom), Cambridge Medical Diagnostics (CMD Limited, Bournemouth, Hants, United Kingdom), Amerlex (Amersham International PLC, Amersham, 
Bucks, United Kingdom), and Farmos Diagnostica (Farmos Diagnostica, Olunsalo, Finland). $17 \alpha$-hydroxyprogesterone and androstenedione were assayed by unpublished in house standard radioimmunoassay techniques entailing diethylether extraction, tritium labelling, and charcoal separation.

\section{Results}

Tables 2-4 show steroid concentrations in plasma and urine from 10 subjects without cysts and the two subjects with theca-lutein ovarian cysts compared with those in normal non-pregnant women of reproductive age.
Table 2 lists the principal steroid metabolites found in urine from normal adults on gas chromatographic analysis, and Table 3 lists those additional compounds found in significant amounts only in the subjects with cysts. Table 4 compares plasma steroid hormones and urinary metabolites between the groups.

Fig. 3 shows a gas chromatogram of urinary steroids in case 2 . That obtained for case 1 was qualitatively very similar. Excretion of the following steroids was raised: pregnanetriol, pregnanediol, and the $\mathrm{C}_{19}$ androgens, androsterone, aetiocholanolone and DHA, together with their hydroxylated products. The $\mathrm{C}_{21}$ corticoids are increased in case 2 and within normal limits in case 1 . In addition, oestrogen excretion was grossly increased (Table 4).

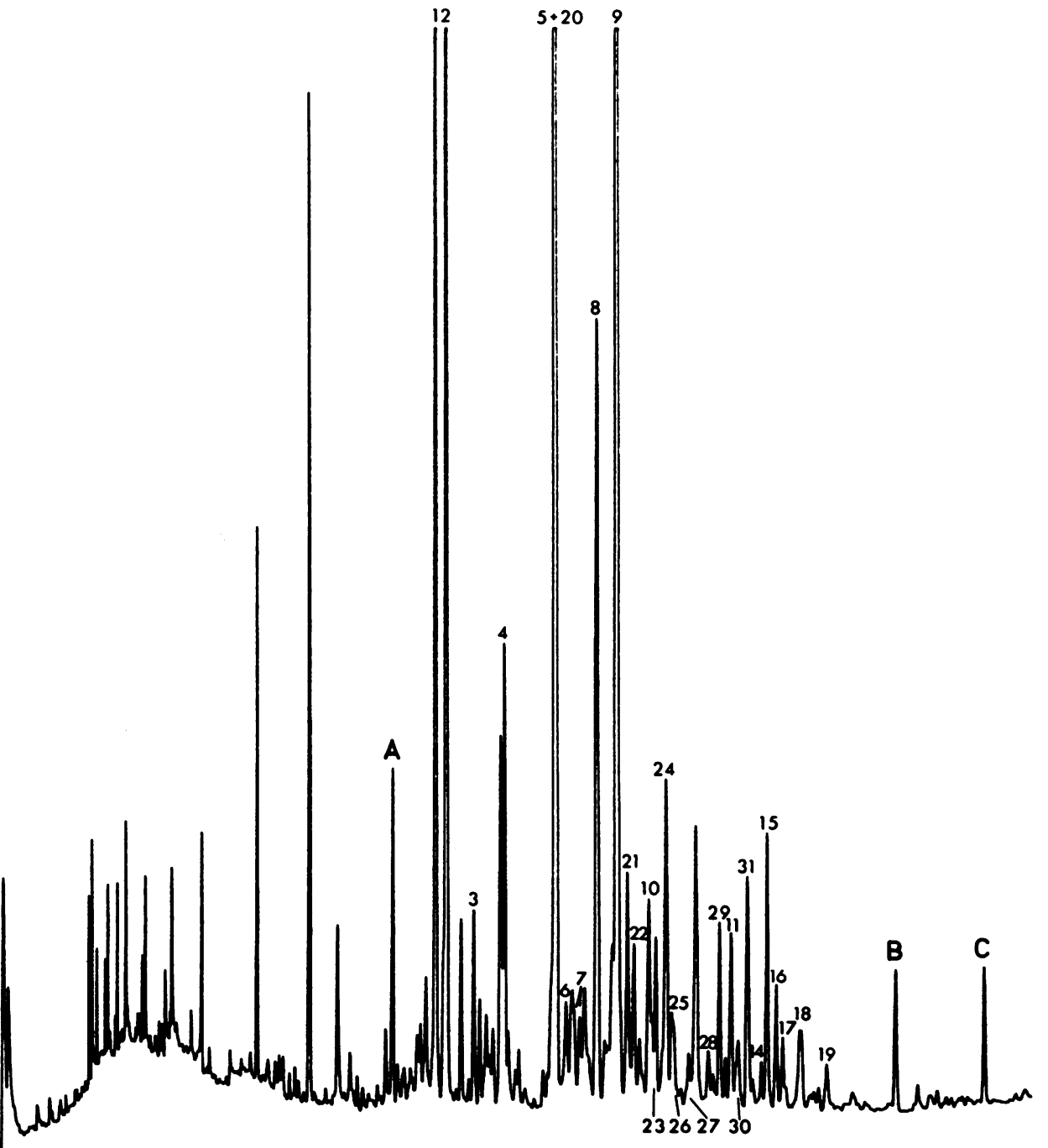

Fig. 3 Capillary gas-liquid chromatogram of urinary steroids in case 2. Numbers refer to steroids in Tables 1 and $2 A B C$ internal standards $=5 \alpha$-androstane-3 $\alpha$-diol, stigmasterol, and cholesteryl butyrate, respectively. 


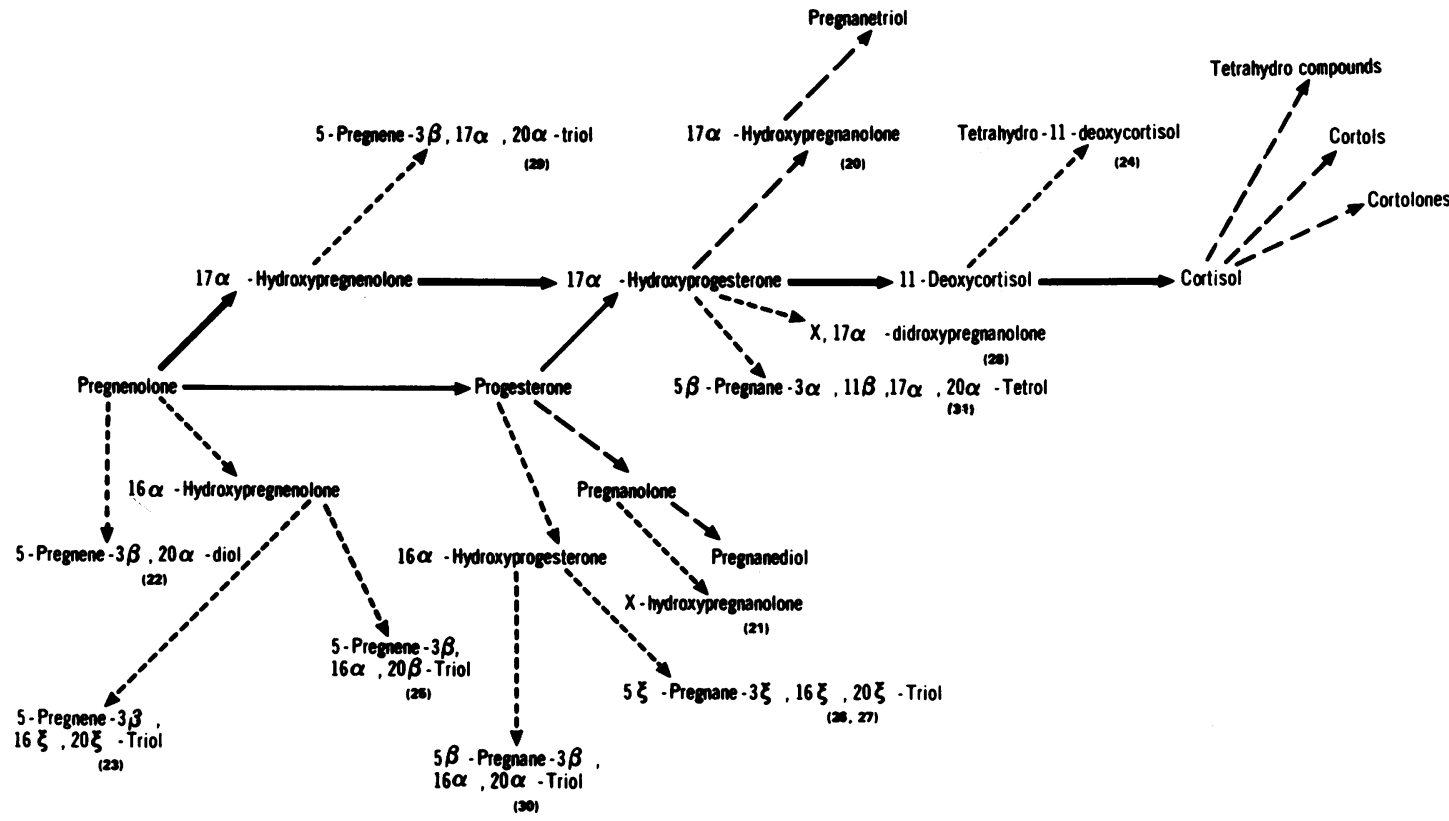

Fig. 4 Major $\left(\Delta_{5}\right)$ and minor $\left(\Delta_{4}\right)$ pathways of cortisol synthesis shown by heavy and light continuous lines, respectively. Pathways leading to the formation of normal and additional steroids shown by dashed and dotted lines, respectively. Numbers in parentheses refer to steroids listed in Table 2. Compound $21-\mathrm{X}=16 \alpha$ ? Compound $28-\mathrm{X}=3 \alpha$ ?

The predominance of $17 \alpha$-hydroxypregnanolone and pregnanetriol is also a feature of steroid excretion in 21-hydroxylase deficiency. There were, however, few similarities between the other components of the profiles. There were several 16-hydroxylated metabolites present in the subjects, but these are almost absent in 21-hydroxylase deficiency (Fig. 4). Recently, the presence of several 15-hyroxylated metabolites has been shown in 21-hydroxylase deficiency (Taylor NF, unpublished observations). There was no trace of these in either of the patients studied.

\section{Discussion}

STEROIDOGENESIS IN TROPHOBLASTIC TISSUE Several investigators have assessed the capacity of trophoblastic tissue for steroidogenesis. Huang et al $^{3}$ cultured trophoblastic tissue and showed synthesis of progesterone. Bahn et al cultured choriocarcinoma cells and confirmed in incubation studies that the main steroid synthesised was progesterone. Lesser quantities of pregnenolone and minimal quantities of 17 $\alpha$-hydroxyprogesterone and $17 \alpha$-hydroxypregnenolone were also detected. Addition of calf serum to the incubates resulted in only minor increments in synthesis of any of these steroids but, in contrast, facilitated a many fold increase in oestradiol production, probably by providing androgen precursors. As expected, addition of $\frac{\partial}{\square}$ androgens stimulated oestradiol synthesis. The $\varrho$ authors concluded that trophoblastic tissue lacked $\overrightarrow{\overrightarrow{0}}$ 17-20 desmolase and 17 $\alpha$-hydroxylase, but that 3 $3 \beta$-hydroxysteroid dehydrogenase, $\Delta_{4} \rightarrow \Delta_{5}$ isomerase, $17 \beta$-hydroxysteroid dehydrogenase, and aro-? matase were all active. Similar results were obtained by Maeyama $e^{a l^{5}}$ in homogenates of choriocarcinoma tissue in that they too were unable to show sidechain cleavage.

Conflicting results, however, were reported by van Leusden, ${ }^{13}$ who obtained evidence for side chain 0 cleavage when incubating tritiated pregnenolone with chorionepithelioma tissue and showed the formation $\frac{7}{0}$ of androsterone, testosterone, oestrone, and oestradiol. The reason for the discrepancies in this or work and that of the Maeyama and Bahn groups is N not clear but may be due to the nature of the tissue studied by the different authors. Van Leusden $\frac{\omega}{\sigma}$ investigated uterine chorionepithelioma, a primary focus, whereas Maeyama's group used cerebral meta- $\stackrel{\varrho}{=}$ static tissue, and Bahn et al cultured chorionepithelioma cells.

In most cases of trophoplastic disease plasma oestrogen and progesterone concentrations have been $\overrightarrow{\mathbb{D}}$ found to be low or within normal limits for non preg- $\frac{?}{\oplus}$ nant subjects, ${ }^{2}$ and urinary pregnanediol and $\varrho$ oestrogen excretions have also been found to be low compared with those found in normal pregnancy. ${ }^{1} 8$ 
On the basis of plasma progesterone assays Teoh et al $^{14}$ considered that choriocarcinoma tissue had only a limited capacity for steroidogenesis. Dawood, ${ }^{1}$ however, asserted that plasma progesterone concentrations correlated with the degree of differentiation of the trophoblastic tissue-concentrations were low in avillous carcinoma but higher in cases of invasive mole and villous carcinoma. He also found a correlation between hCG concentrations and progesterone in choriocarcinoma and believed that the ovaries were the principal source of the progesterone under stimulation from hCG.

Sadoff et $\mathrm{l}^{15}$ reported that in a male patient with metastatic choriocarcinoma, pretreatment plasma concentrations of cortisol, testosterone, and oestradiol were all grossly increased. High hCG values in the cerebrospinal fluid showed that the patient had developed cerebral metastases. Cerebrospinal fluid steroid concentrations, however, were low, suggesting that it was unlikely that the metastatic tissue was the source of the raised plasma steroids, and, more probably, that they had originated from the testis or adrenal gland, or both.

\section{STEROIDOGENESIS BY THECA-LUTEIN CYSTS}

Ovarian follicles are known to possess the capacity for side chain cleavage of $\mathrm{C}_{21}$ steroids and also $17 \alpha$-hydroxylase and $16 \alpha$-hydroxylase activities: they lack $11 \beta$ - and 21 -hydroxylase activities. ${ }^{16}$ Steroid values in fluid from pre-ovulatory follicles and in thecalutein cysts have been reported as being very similar. ${ }^{17}$ The principal progestins present, such as progesterone, 17 $\alpha$-hydroxyprogesterone, 16 $\alpha$-hydroxyprogesterone, and 20-dihydroprogesterone, are potential precursors of the additional compounds identified in cases 1 and 2 (Table 3 and Fig. 4). Likewise, the principal androgens reported, DHA sulphate and androsterone sulphate, might account for the high concentrations of the urinary androgen metabolites, androsterone, aetiocholanolone, and $16 \alpha$-hydroxy DHA. Oestradiol concentrations were relatively lower in cyst fluids than in normal follicles, and interestingly, in our patients with ovarian cysts oestrogen concentrations were proportionately less raised than were progesterone and $17 \alpha$-hydroxyprogesterone and their metabolites.

There have been comparatively few other assessments reported on the contribution of theca-lutein cysts to steroidogenesis, and most published reports have been concerned with steroid production in hydatidiform moles. Stitch et al $^{18}$ reported a case of molar pregnancy associated with increased urinary pregnanetriol excretion. At the time of removal of the mole by abdominal hysterectomy the ovaries were seen to contain massive theca-lutein cysts, which were believed to have enlarged further immediately after the operation: concomitantly, urinary pregnanetriol output became even higher than before and only returned to normal as the cysts regressed. The authors considered the cystic ovaries to be the most likely source of the pregnanetriol precursors.

Reporting on a similar case of hydatidiform mole with theca-lutein cysts and increased urinary pregnanetriol excretion, Coutts et al ${ }^{19}$ concluded that, although molar tissue was active in steroid metabolism, the excessive pregnanetriol originated from the polycystic ovaries. In support of these conclusions evidence was presented that whereas molar tissue contained pregnenolone, $17 \alpha$-hydroxypregnenolone, pregnanediol, pregnanetriol, and androstenedione, $17 \alpha$-hydroxyprogesterone was undetectable and progesterone present only in trace amounts. On the other hand, theca-lutein cyst fluid was found to contain all these steroids, progesterone and $17 \alpha$-hydroxyprogesterone being present in considerable quantities.

Dawood, Ratnam, and $\mathrm{Teoh}^{20}$ and Dawood ${ }^{21}$ investigated molar pregnancies with and without theca-lutein cysts. They showed that in both "intact" moles - that is, before loss of vesicular tissue - and aborted moles the presence of ovarian cysts was accompanied by higher plasma oestradiol and progesterone concentrations. They suggested that molar tissue was an active steroidogenic tissue but that there was additional steroid synthesis from the ovary when theca-lutein cysts were present.

The only report concerning the effect of cystic ovaries is that of Samaan $e a^{22}$ who reported raised plasma testosterone concentrations in women with trophoblastic disease and showed that the highest testosterone values were seen in those patients in whom the ovaries were grossly enlarged. Oophorectomy and chemotherapy were effective in reducing both hCG and testosterone values. Cyst fluid was obtained at laparotomy from the ovaries of a patient with metastatic trophoblastic disease and enlarged ovaries, and it was shown that the content of testosterone was much higher than in the circulation. It was suggested that the ovarian cysts might be a principal site of testosterone formation but, because oophorectomy was not required in this patient, they were unable to rule out other possible sites of testosterone production.

In the patients with trophoblastic disease complicated by the presence of ovarian theca-lutein cysts reported here the principal steroids present in excess in serum and urine were similar to those shown by Vanleuchene et $\mathrm{l}^{17}$ to be the normal constituents of lutein cyst fluid. They also comprised the steroids shown by $A_{b r a h a m}{ }^{23}$ to be those that peak at mid cycle and are not diminished by dexamethasone suppression, indicating an ovarian origin.

The report of Teoh et al ${ }^{14}$ that choriocarcinoma 
tissue has only a limited capacity for steroidogenesis, and the suggestion by Sadoff et al $^{15}$ that metastases were unlikely to be the source of raised plasma steroids in metastatic choriocarcinoma support the concept that the most probable source of the abnormal and grossly raised steroids in our patients were the large ovarian cysts. The available evidence suggests that, similarly to ovarian tissue, theca-lutein cysts possess the enzymes required for progestin, androgen and oestrogen synthesis. We suggest that the secretions result from the enormous proliferation of thecalutein cells under the influence of excessive circulating hCG.

We also suggest that the additional steroids in the profiles of the cystic subjects arose from saturation of the normal metabolic excretion pathways, such that sufficient substrates were available for the activation of other pathways, present in all subjects but normally only minimally used, thus resulting in the observed bizarre excretion patterns. Fig 4 shows the possible metabolic pathways. These suggestions, however, can only be advanced with caution because of the incomplete characterisation of several of the steroids in the profile. In addition, a possible contribution from the trophoblastic tissue to steroid synthesis cannot be ignored.

To confirm the source of the "abnormal" steroids of the type described, which, at least superficially, mimic 21-hydroxylase deficiency, we suggest that simultaneous measurement of the steroids in both cyst fluid and the general circulation should be carried out in cases of trophoblastic disease with ovarian enlargement. It may also be of interest to measure the steroid content of the same two tissues in cases of hyperstimulation following follicle stimulating hormone treatment for infertility. The absence of trophoblastic tissue in infertility would certainly lead to a more accurate assessment of the likely source.

We thank Dr JW Honour for his help with the initial stages of the study, Mrs DK Patel for help with the steroid profiling, and Mrs TM Coe and Mr MJ Madigan for carrying out the mass spectrometry. The work of the technical staff of the endocrine laboratory, Jessop Hospital for Women, headed by Mr R Hall and Mrs CM Blair in carrying out the urinary and serum steroid assays is most gratefully acknowledged. Thanks are also due to Mrs A Walters and Mrs C Box, and in particular, to Mrs CJ Kennard and Mrs DS Kilner for their invaluable help in preparing the manuscript.

\section{References}

${ }^{1}$ Dawood MY. Serum progesterone and serum human chorionic gonadotrophin in gestational and nongestational choriocarcinoma. Am J Obstet Gynecol 1975;123:762-5.
${ }^{2} \mathrm{Li}$ MC. Trophoblastic disease: natural history, diagnosis and treat- $\frac{\stackrel{0}{7}}{\overrightarrow{2}}$ ment. Ann Intern Med 1971;74:102-12.

${ }^{3}$ Huang WY, Patillo RA, Delfs E, Mattingley RF. Progesterone synthesis in the pure trophoblast of human choriocarcinoma. Steroids 1969;14:755-63.

${ }^{4}$ Bahn RS, Worsha A, Speeg KV Jr, Ascoli M, Rabin D. Characterisation of steroid production in cultured human choriocarci- $\bar{O}$ noma cells. J Clin Endocrinol Metab 1981;52:447-50.

${ }^{5}$ Maeyama M, Ifuku M, Nakahara K. Steroidogenesis in cerebral $\vec{D}$ metastatic chorionepithelioma tissue in vitro. J Endocrinol $\varrho$ 1975;65:425-8.

${ }^{6}$ Bagshawe KD. Choriocarcinoma: the clinical biology of the tro- 1 phoblast and its tumours. London: Edward Arnold, 1969:257-63.

${ }^{7}$ Shackleton CHL, Whitney JO. Use of Sep-Pak cartridges for uri- $\overrightarrow{\vec{\omega}}$ nary steroid extraction: evaluation of the method for use prior to $\vec{\omega}$ gas chromatographic analysis. Clin Chim Acta 1980;107:231-43. 으

${ }^{8} \mathrm{Kwan}$ TK, Taylor NF, Gower DB. The use of steroid profiling in the resolution of pregnenolone metabolites from porcine testicular preparations. J Chromatogr 1984;301:189-97.

${ }^{9}$ Lever M, Powell JC, Peace SM. Improved estriol determination in a continuous flow system. Biochem Med 1973;8:188-98.

${ }^{10}$ Podmore DA. Routine determination of urinary pregnanediol $V$ using gas chromatography with automatic sample application. 으 J Clin Pathol 1966;19:619-21.

${ }^{11}$ Curtius HC. Gas chromatographische Bestimmung von preg- nanediol, pregnanetriol und pregnanetriolon in urin. Zeitschrift $\subseteq$ für Klinische Chemie und Klinische Biochemie 1966;4:114-9.

${ }^{12}$ Gray CH, Baron DN, Brookes RV, James VHT. A critical appraisal of a method of estimating urinary 17-oxosteroids and $\vec{\varphi}$ total 17-oxogenic steroids. A memorandum prepared at the re- $\infty$ quest of the Clinical Endocrinology Committee of the Medical Research Council. Lancet 1969;i:124-7.

${ }^{13}$ Van Leusden HA. Hormonal changes in pathological pregnancy. Vitamins and Hormones 1972;30:281-361.

14 Teoh ES, Das NP, Dawood MY, Ratnam SS. Serum progesterone and serum chorionic gonadotrophin in hydatidiform mole and $\frac{\mathrm{O}}{\mathrm{O}}$ choriocarcinoma. Acta Endocrinol 1972;70:791-800.

15 Sadoff L, Riley S, Quan L, Rowe J. New endocrine observations in $\overrightarrow{\vec{F}}$ a male patient with choriocarcinoma. Oncology 1974;29:227-37.

${ }^{16}$ Sano V, Okinaga S, Arai K. Effects of ovarian steroids on the $17 \alpha$-hydroxylase activity towards progesterone in a human ovarian follicle at the late follicular phase. $J$ Steroid Biochem? 1983;18:55-8.

${ }^{17}$ Vanleuchene E, Vandekerckhove D, Jonckheere J, DeLeenheer A. $\frac{\widehat{O}}{0}$ Steroid profiles of body fluids other than urine, obtained by 0 capillary gas chromatography. J Chromatogr 1983;279:573-80.

${ }^{18}$ Stitch SR, Levell MJ, Oakey RE, Scott JS. Excretion of pregnanetriol in a case of hydatidiform mole associated with ovarian theca-lutein cysts. Lancet 1966;i:1344-7.

${ }^{19}$ Coutts JRT, MacNaughton MC, Ross PE, Walker J. Steroido- 응 genesis in a case of hydatidiform mole. $J$ Endocrinol 1969;44:335-48.

${ }^{20}$ Dawood MY, Ratnam SS, Teoh ES. Serum oestradiol-17 $\beta$ and serum human chorionic gonadotrophin in patients with hy- $\mathrm{N}$ datidiform moles. Am J Obstet Gynecol 1974;119:904-10.

${ }^{21}$ Dawood MY. Progesterone concentrations in the sera of patients with intact and aborted hydatidiform moles. Am J Obstet Gynecol 1974;119:911-18.

${ }^{22}$ Samaan NA, Smith JP, Rutledge FN, Barcellona JM. Plasma 0 testosterone levels in trophoblastic disease and the effects of oophorectomy and chemotherapy. J Clin Endocrinol Metab 1972;34:558-61.

${ }^{23}$ Abraham GE. Ovarian and adrenal contribution to peripheral androgens during the menstrual cycle. $J$ Clin Endocrinol Metab $\square$ 1974;39:340-6.

Requests for reprints to: Dr GW Pennington, The Jessop Hospital for Women, Leavygreave Road, Sheffield S3 7RE, ® England. 